\title{
Guerra à guerra. Violência e anticolonialismo nas oposições ao Estado Novo
}

War on War: Violence and Anti-colonialism in the Opposition to the New State Guerre à la Guerre. Violence et anticolonialisme dans les oppositions à l'État Nouveau

\section{Miguel Cardina}

\section{OpenEdition}

\section{Journals}

\section{Edição electrónica}

URL: http://journals.openedition.org/rccs/1743

DOl: $10.4000 /$ rccs. 1743

ISSN: 2182-7435

\section{Editora}

Centro de Estudos Sociais da Universidade de Coimbra

Edição impressa

Data de publição: 1 Março 2010

Paginação: 207-231

ISSN: 0254-1106

\section{Refêrencia eletrónica}

Miguel Cardina, « Guerra à guerra. Violência e anticolonialismo nas oposições ao Estado Novo »,

Revista Crítica de Ciências Sociais [Online], 88 | 2010, colocado online no dia 01 outubro 2012, criado a 30 abril 2019. URL : http://journals.openedition.org/rccs/1743 ; DOI : 10.4000/rccs.1743 


\title{
MIGUEL CARDINA
}

\section{Guerra à guerra. Violência e anticolonialismo nas oposições ao Estado Novo'}

\begin{abstract}
Durante a década de sessenta, numa altura em que o mundo ia assistindo à consolidação triunfante dos independentismos anticoloniais, a ditadura portuguesa persistia em manter o seu domínio ultramarino. Apesar de limitados nos seus direitos de expressão e associação, alguns sectores da sociedade foram construindo um horizonte de intervenção fortemente crítico do colonialismo do regime. Este texto pretende caracterizar a prática e o discurso de uma destas áreas, no caso a pulverizada corrente maoísta, contextualizando previamente a ideia de violência nas leituras sobre os "longos anos sessenta" e a especificidade do maoísmo emergente nesse tempo.
\end{abstract}

Palavras-chave: anos sessenta; anticolonialismo; Estado Novo; maoísmo; radicalismo; resistência.

\section{Introdução}

Se a divisa "make love, not war" se tornou um símbolo constantemente evocado para dar conta do tipo de contestação produzida durante os "longos anos sessenta" (Jameson, 1984; Marwick, 1998), o certo é que os gestos e os discursos oriundos desse período nem sempre corresponderam a esta imagem pacifista, por vezes entendida retrospectivamente como individualista e despreocupada. Em diferentes tempos e lugares, e a um ritmo progressivamente intensificado, a nova cultura juvenil introduziu profundas transformações no domínio dos costumes, do gosto e da moral e accionou zonas de ousadia e resistência que muitas vezes evoluíram para o confronto aberto com os códigos da sociedade burguesa. Com efeito, a experiência sixtie, nomeadamente na sua vertente radical e politizada, promoveu uma

\footnotetext{
${ }^{1}$ A pesquisa para este trabalho realizou-se no âmbito de um projecto de doutoramento que conta com o apoio da Fundação para a Ciência e a Tecnologia (ref. n. ${ }^{\circ}$ SFRH/BD/22796/2005). Cumpre-me agradecer muito particularmente a Rui Bebiano pela forma próxima, crítica e rigorosa como tem acompanhado este percurso enquanto orientador científico do projecto, mas também pelos estimulantes escritos que tem produzido sobre a especificidade dos "longos anos sessenta" em Portugal e que, em grande medida, inspiram o presente artigo.
} 
nova conflitualidade de natureza fracturante e transgressora que, mais do que recusar a violência, questionava o seu significado e procurava redefinir a sua aplicação.

Em Portugal, e apesar dos entraves socioculturais e políticos, alguns sectores, essencialmente procedentes dos meios estudantis, mostraram-se abertos à influência de um certo "espaço 68" (Frank, 2000). Este fenómeno cruzou-se, no país, com o aparecimento de um novo tipo de contestação à Guerra Colonial, na qual o activismo promovido pelas franjas maoístas teve um papel relevante. Condenando a retórica belicista e nacionalista do Estado Novo, estes grupos não deixaram de entender a violência como um meio indispensável para se alcançar uma desejada "sociedade sem classes". Este artigo pretende, num primeiro momento, contextualizar a ideia de violência nas leituras prevalecentes sobre os anos sessenta e mostrar o lugar e o impacto do maoísmo no período. De seguida, apontam-se alguns elementos da prática e do discurso deste múltiplo território político no declínio da ditadura portuguesa, salientando a sua contribuição para a construção de um campo social resolutamente anticolonial.

\section{A ideia de violência nos anos sessenta}

A questão da violência tem sido frequentemente evocada quando se trata de interpretar o conteúdo e o legado dos anos sessenta (Varon, 2004; Bebiano, 2005). Algumas leituras mais conservadoras propendem mesmo a associar o tempo a uma vertigem de destruição da ordem estabelecida. No seu influente The Conflict of Generations, Lewis Feuer fala de "componentes autodestrutivas e irracionais de todos os movimentos estudantis" (1969: 102). Servindo-se igualmente da ideia de um niilismo emanado do período, Allan Bloom (1987) critica a desvalorização das "Grandes Obras" originada pelo pensamento radical dos anos sessenta. Com uma alusão mais concreta aos eventos parisienses de "Maio de 68", Raymond Aron fala de um delírio carnavalesco levado a cabo por "bárbaros inconscientes da sua barbárie" (1968: 13). Este discurso denunciador foi, aliás, reabilitado por Nicolas Sarkozy durante a campanha presidencial francesa de 2007, acusando "Maio de 68 " de ter criado uma sociedade na qual a hierarquia, a autoridade e a paz social são frequentemente postas em causa, o que, na interpretação de Alain Badiou (2008), resulta do facto de aquele acontecimento ter sido uma das últimas manifestações reais do "espectro do comunismo".

De maneira diferente, o americano Todd Gitlin (1987), associando a década a um território bipolar de esperança e raiva, sugere a existência de uns "bons" anos sessenta, constituídos pela oposição à guerra do Vietname e pela luta em torno dos direitos cívicos, claramente diferente dos "maus" anos 
sessenta, preenchidos por combates de efeito destruidor e frequentemente destituídos de objectivos a longo prazo. Para Max Elbaum (2002), pelo contrário, os dias de fúria do final dos anos sessenta marcam um avanço na contestação e não correspondem a um mero período de ressaca ou desânimo. $\mathrm{Na}$ opinião deste antigo activista, não só os troços temporais de 1960-64 e 1968-73 reclamaram diferentes engajamentos - o que significa que nenhuma análise do período pode ser realizada fora do contexto político mais vasto de onde irradiou -, como os chamados "maus" anos sessenta foram, na verdade, um tempo de crítica sistémica às estruturas políticas, dinamizando fatias sociais significativas.

Outros, como é o caso de Arthur Marwick, sublinham a coexistência de fluxos contrastantes mas complementares, integrados num conjunto de mutações destinadas a questionar o establishment vigente. Na sua obra monumental sobre o período, o historiador britânico dedica mesmo todo um capítulo ao tema da violência, anotando que "é inútil dividir os anos sessenta entre uma primeira metade optimista e pacífica e uma segunda metade violenta e pessimista", já que muitas vezes a violência da segunda fase emanou, precisamente, de movimentos emergentes na primeira metade (1998: 533-583).

No seu trabalho comparativo sobre a guerrilha urbana levada a cabo pelos americanos Weather Underground e pela germânica RAF (Rote Armee Fraktion), Jeremy Varon (2004:3) anota a existência, no campo da esquerda radical, de debates mais ou menos disseminados sobre a questão da violência, quer em sentido defensivo, contra a repressão policial, quer em sentido ofensivo, como alavanca para uma necessária mudança social. Paul Berman (2007: 47-48), por seu turno, considera que os debates se centravam essencialmente na questão do criptonazismo da vida moderna e dos meios para o afrontar. A questão da violência/não-violência seria um assunto do foro táctico, frequentemente baralhado no contexto concreto do activismo, e que emergiu com maior vigor a partir de 1969, porque a guerra do Vietname se intensificara, o movimento anticolonial dava mostras de poder caminhar num sentido mais radical e a experiência efectiva de recontros com a polícia conduzia a crescentes acessos de cólera.

\section{O radicalismo da "nova esquerda"}

O radicalismo das décadas de sessenta e setenta caracterizou-se pela adopção de um imaginário de rebeldia baseado em novos referenciais éticos, estéticos e políticos de traços internacionalistas e combativos. Esta tendência de renovação não se alicerçou num corpo unificado de teses, mas antes em múltiplos, e por vezes conflituantes, contributos. Ainda assim, é possível 
identificar alguns traços comuns. Em primeiro lugar, o combate à alienação, não só económica, mas também psicológica, sexual, cultural e ideológica. Em segundo lugar, a crítica às formas tradicionais de autoridade, estendendo-se a apreciação, em alguns casos, à própria noção de autoridade. Em terceiro, a crítica da vida quotidiana, insistindo-se num modelo de socialismo indissociável de uma necessária e radical alteração no plano dos costumes e das mentalidades e não apenas assente na revolução política e social. Por fim, a valorização do papel da juventude enquanto agente de mudança, substituindo ou acompanhando o proletariado na histórica missão de transformação social que o marxismo the havia identificado (Katsiaficas, 1987: 23-27).

Designadamente no mundo anglo-saxónico e alemão, esta amálgama plural foi correntemente designada como "nova esquerda", ainda que muitos segmentos permanecessem fiéis à "velha esquerda" marxista e ao seu postulado da organização dos trabalhadores industriais como método de transformação da sociedade. Este movimento terá contemplado três vertentes. A primeira delas consistiu num retorno ao velho "marxismo sectário", organizando "estruturas leninistas disciplinadas baseadas na obediência, dedicação e auto-sacrifício". A segunda corrente era constituída pelo "marxismo de Ho, Mao, Che e Fidel, misturado com algumas doutrinas dos filósofos da Escola de Frankfurt", apresentando-se por vezes sem um enquadramento organizacional bem definido. A terceira alternativa apoiava-se no impulso libertário de Kropotkine, Bakunine, dos conselhistas holandeses ou dos situacionistas franceses, bem como "numa brisa que soprava pelos bairros universitários e nos rumores da contracultura da Califórnia" (Berman, 2007: 48-50).

Apesar das diferenças relevantes entre os conjuntos referidos, é possível encontrar um ponto de intersecção entre os pedaços deste emergente caleidoscópio, e que consistia num mesmo posicionamento equidistante, quer das modernas sociedades de consumo ocidentais, de onde o movimento brotou de sobremaneira, quer do burocratismo soviético. Estes novos grupos insubmissos encontravam-se unidos na defesa da democracia participativa e do internacionalismo, na utilização de formas de protesto arrojadas, e na proclamação do sonho comum de levar a cabo uma revolução que derrubasse, quer o imperialismo ocidental, simbolizado pelos EUA, quer o comunismo mumificado de Leste.

Assim, o socialismo emanado de Moscovo foi sendo rejeitado por uma constelação de grupos que, no meio das suas diferenças significativas, convergiam na mesma condenação da democracia formal burguesa e do aparelhismo e reformismo da esquerda pró-soviética. Dito de outro modo, todos 
eles manifestavam frequentemente um interesse por Marx, exibiam uma atitude revolucionária e consideravam-se à esquerda dos partidos comunistas tradicionais, que atacavam com distintos graus de virulência. De facto, a partir da segunda metade da década de 1950, uma série de novos acontecimentos veio pôr em causa a imagem de exemplaridade do regime soviético. Registe-se o questionamento do estalinismo no XX Congresso do PCUS, as insurreições na Polónia e na Hungria, em 1956, o conflito sino-soviético e a invasão da Checoslováquia, em Agosto de 1968. Ao mesmo tempo, as lutas dos movimentos independentistas africanos e asiáticos, a imagem informal da revolução cubana e a leitura empolgada e, na maioria das vezes, truncada e deficiente, do fenómeno chinês, pareciam mostrar que a transformação revolucionária da sociedade era possível segundo modelos aparentemente novos e, por isso mesmo, dotados de um evidente magnetismo.

Em todos estes casos, a violência emergia como um caminho inevitável que conduziria a uma necessária regeneração social. Um livro clássico do pensamento anticolonial, Os condenados da Terra, de Franz Fanon, afirmava que "a descolonização é sempre um fenómeno violento" (2002: 39), o que - como sublinhou Immanuel Wallerstein em artigo recente - era tanto uma observação analítica como uma recomendação política (2008: 5). Mesmo em sectores influenciados pela imagética pacifista, a hostilidade ao imperialismo unia esta imprecisa mas aguerrida nova esquerda, accionando gestos e atitudes de admiração relativamente a figuras tão distintas como Che Guevara, Fidel Castro, Malcolm X, Amílcar Cabral, Angela Davis, Mao Tsé-Tung ou Ho Chi Minh. Como cantou o chileno Victor Jara a respeito deste último líder político, a luta independentista do Vietname configurava-se como um modo decidido de reivindicar "el derecho de vivir en paz" ao mesmo tempo que afrontava uma agressão imperialista que, apesar de localizada, golpeava a humanidade inteira.

\section{A difusão internacional do maoísmo}

O "maoísmo internacional" baseou-se na evocação constante da luta de classes e na defesa da guerra revolucionária como forma de alcançar o poder. Deste modo, incentivou a ideia segundo a qual somente pela força das armas se pode expurgar as máculas do mundo, o que era atestado por algumas citações de Mao Tsé-Tung, como aquela que exprimia a certeza de que “o poder nasce na ponta da espingarda" (Citações, 1972: s.n.). Esta imagem combativa criava, por si só, simpatias entre o meio militante. A título ilustrativo, anote-se a resposta dada por Eldridge Cleaver, destacado membro dos americanos Black Panthers, citado pelo maoísta americano Bob Avakian. Questionado acerca da razão pela qual tinha um poster de Mao na parede, 
assevera Cleaver: "porque ele era o maior sacana do planeta" ["because Mao is the baddest motherfucker on the planet earth"] (Avakian, 2005: 167). A "sinofilia" ocidental alimentava-se igualmente de leituras apologéticas feitas por intelectuais que se deslocaram à China - como é o caso de Maria Antonietta Macchiocchi, Charles Bettelheim, K.S.Carol, Julia Kristeva ou Alberto Moravia - e que ajudaram a transplantar para território ocidental o mito de uma revolução em constante processo de actualização, tutelada pelo rosto demiúrgico do "Presidente Mao".

Depois do corte anarquista na I Internacional, da ruptura consumada com a social-democracia no final da I Guerra Mundial, no âmbito da II Internacional, e do dissídio trotskista durante a década de 1930 do século xx, o maoísmo representou o quarto grande cisma na história do socialismo e do comunismo. Com a morte de Estaline, em 1953, e a denúncia krutcheviana do "culto da personalidade" no decorrer do XX Congresso do PCUS, em 1956, inicia-se uma nova fase. A partir dessa data, as divergências entre a China e a União Soviética vão-se agravando até à ruptura total, no início da década de sessenta. Para os chineses, a tese soviética da "coexistência pacífica" significava um abandono efectivo da luta entre comunismo e imperialismo, convicção que esteve na base da criação de múltiplas organizações pró-chinesas por todo o mundo. Para os soviéticos, a posição chinesa revelava-se imprudente tendo em conta a correlação de forças no contexto internacional e fomentava no limite um conflito nuclear generalizado (Lüthi, 2008).

O único partido comunista no poder que apoiou a dissidência chinesa foi a Albânia, em 1961. Do conjunto de grupos emergentes num primeiro momento destaca-se, na Europa, o grupo liderado por Jacques Grippa, constituído após uma importante cisão no Partido Comunista Belga, e que se estabeleceu como um centro internacional de reagrupamento dos "marxistas-leninistas" até finais da década de sessenta, altura em que a China retirou a confiança ao colectivo. Se, no território europeu, rapidamente aparecem grupos de observância maoísta em dezoito países, foi nos lugares do chamado "Terceiro Mundo" - nomeadamente na América Latina e sobretudo na Ásia - que esta corrente política alcançou maior sucesso (Alexander, 1999; Alexander, 2001; Pereira, 2008).

A dissensão entre a União Soviética e a China, ocorrida nos alvores da década de sessenta, alimentou rupturas ocorridas no interior dos partidos comunistas dos diferentes países, centradas na questão das alianças estratégias e no papel da violência revolucionária, levando à constituição de pequenos grupos autodesignados "marxistas-leninistas". Uma segunda vaga, mais declaradamente maoísta, veio a afirmar-se no final da década de sessenta, 
motivada pelo impacto da revolução cultural chinesa, com a consequente certeza de que a transformação do mundo era um processo alimentado pelo questionamento permanente às estruturas hierárquicas constituídas, mesmo que estas tivessem uma formatação socialista. Esta segunda vaga teve sobretudo expressão nos meios juvenis radicais, junto de sectores que, em regra, nunca militaram nos partidos comunistas tradicionais e que, apesar do discurso ferreamente leninista, mantinham proximidades de fundo com o activismo voluntarista de um certo anarquismo histórico.

Esta dupla filiação levou a que o militantismo pró-chinês se inscrevesse de maneira oscilante entre o protesto disciplinar e antidisciplinar que, na opinião da australiana Julie Stephens (1998), caracterizou o radicalismo dos anos sessenta. Se o maoísmo se afastou dos traços mais hedonistas e individualistas da época, a verdade é que também não foi imune a modos de estar, agir e sentir de timbre filo-libertário. No interior dos vários grupos e, por vezes, no próprio íntimo dos militantes, o imaginário da rebelião como "festa" debateu-se com a recusa da dimensão hedonista da contestação; a experimentação pessoal e a abertura em termos de costumes confrontaram-se com o puritanismo e a "moral proletária"; a recepção das heterodoxias teóricas teve pela frente o dogmatismo e a vulgata ideológica; a sedução das armas conflituou com a necessidade de desenvolver um aturado trabalho com "as massas".

$\mathrm{Na}$ realidade, é necessária alguma atenção para não se homogeneizar excessivamente este campo político. Belden Fields, num estudo comparativo sobre o maó́smo e o trotskismo em França e nos Estados Unidos, fala da existência, no contexto francês, de um "maoísmo hierárquico" e de um "maoísmo anti-hierárquico" (1998: 87 e 226). Na mesma direcção, Marnix Dressen divide as organizações em "lenino-maoístas" - entre as quais se enquadram as mais antigas Union des Jeunesses Communistes Marxistes-Leninistes (UJCML) e o Parti Communiste Marxiste-Leniniste de France (PCMLF), oficialmente reconhecido pela China - e "anarco-maoístas" caso da Gauche Prolétarienne e da sua efémera cisão Vive la Revolution! (1999: 21). Em traços gerais, a primeira linha encontrava-se marcada pelo conflito sino-soviético e pela concepção bolchevique da vanguarda proletária, enquanto a segunda linha se definia por uma maior espontaneidade nas atitudes e nas práticas e por uma sedução pelo imaginário da Revolução Cultural chinesa.

\section{Portugal: traços de mudança no ocaso do Estado Novo}

Se é verdade que boa parte das potências europeias não tinha no seu horizonte a independência das colónias africanas, o certo é que o contexto geopolítico emergente da II Guerra Mundial acabou por marcar fortemente 
a dinâmica anticolonial dos anos seguintes. Vista como uma luta contra o expansionismo germânico, a acção vitoriosa dos Aliados serviu para afirmar princípios - exarados na Carta da ONU em 1945, nomeadamente no capítulo XI - que comprometiam os países com colónias a incentivar o desenvolvimento progressivo de instituições políticas livres. Posteriormente, a ONU viria mesmo a preconizar o dever das potências coloniais de preparar os territórios sob sua administração para a independência. Em Abril de 1955, na Conferência de Bandung (Indonésia), reúnem-se vinte e nove países afro-asiáticos, com destaque para a URSS, a China e a Índia, que condenam o colonialismo e apelam à unidade dos povos contra ele.

Em Portugal, uma revisão constitucional operada em 1951 transformou as colónias portuguesas em "territórios ultramarinos", mudança cosmética que visava, na verdade, neutralizar o referido capítulo XI da Carta das Nações. Com este artifício pretendia afirmar-se que o país não possuía colónias mas apenas províncias nacionais que tinham a particularidade notável de se situarem em vários continentes, pese embora o "estatuto do indigenato" em vigor excluísse dos direitos de cidadania portuguesa a esmagadora maioria dos naturais daqueles lugares (Silveira, 1989: 75).

O colonialismo e o culto do Império constituíam, aliás, traves mestras do discurso ideológico do Estado Novo. Ao mesmo tempo que o regime exaltava a ruralidade - Salazar definia-se como católico, "camponês, filho de camponeses", "pobre, filho de pobres" (1951:351) -, baseava-se numa forte mística imperial que identificava o país com a sua incontornável missão civilizadora além-mar. O processo de sacralização do Império aparece, em Portugal, muito ligado, quer à ideia de salvaguarda da sua independência face ao vizinho espanhol no conjunto da Península Ibérica, quer à necessidade de preservar uma imagem de nação associada à "herança sagrada" do período de ouro das "Descobertas" (Alexandre, 2000: 198).

Também por isso, os ventos descolonizadores do pós-guerra atingem muito indirectamente o campo da oposição. À semelhança dos defensores do regime, uma boa parte dos velhos republicanos acreditava que o Império seria a oportunidade de recuperar a "glória perdida" da nação. Importantes oposicionistas, como Ramada Curto e Norton de Matos, eram confessos defensores do colonialismo português, pelo que a questão era marginalizada nos fóruns de discussão política que a ditadura a espaços ia permitindo. Tanto o Programa para a Democratização da República, de 1961, como o manifesto eleitoral de Humberto Delgado, em 1958 - cuja candidatura galvanizou as hostes oposicionistas e assustou de tal maneira o regime que este forjou os resultados e proibiu a realização de eleições presidenciais directas a partir daí - são omissos a esse respeito. 
Os próprios socialistas, agrupados em 1964 em torno da ASP (Acção Socialista Portuguesa), mantêm uma posição ambígua durante a década de sessenta, condenando a política colonial, mas só tarde afirmando o direito à independência dos povos colonizados (Martins, 2005: 178-9). Quando eclode a guerra em Angola, no início de Fevereiro de 1961, apenas o PCP reconhecia o direito à autodeterminação e à independência das colónias. No decorrer do seu V Congresso, em 1957, havia substituído a sua posição anterior, baseada na criação de secções locais do partido nas colónias, por uma outra que consistia em estimular partidos com base e direcção fundamentalmente indígenas e destinados a lutar pela independência (Madeira, 2003; Manya, 2004).

O PCP (Partido Comunista Português) desde cedo erigiu um discurso que oscilava entre uma retórica nacionalista que acentuava os custos da guerra para o país e um "modo proletário", menos visível mas nem por isso totalmente ausente, que vincava a solidariedade internacionalista com os povos das colónias (Neves, 2008). No entanto, a questão que viria a estar no centro de polémicas com os colectivos à sua esquerda resultava da posição a adoptar por parte daqueles que eram chamados a combate. Apesar de afirmar não se opor genericamente às deserções, sobretudo se colectivas, o PCP estimulava os seus membros à recusa das "deserções individuais". Para o partido, a opção mais correcta seria ir tão longe quanto possível, inclusive até aos campos de batalha, para esclarecer os outros soldados e organizar a rejeição ao combate.

Esta posição, contudo, é o resultado de um percurso de reflexão temática efectuado ao longo dos anos sessenta, fenómeno recentemente sublinhado por António Monteiro Cardoso (2009). Assim, em 1961 o Avante! incita os soldados à recusa do embarque e a servirem de força opressiva do povo angolano (Avante!, 1961: 300). Em 1965 e 1966 são comuns os apelos a deserções colectivas, mas tendencialmente se vai acentuando o discurso crítico que coloca o acento tónico no impacto da guerra enquanto sorvedouro de vidas e recursos nacionais. Se o jornal não deixará de falar da deserção colectiva como forma legitima de resistência à guerra, uma resolução sobre deserções, de Julho de 1967, deixa claro que os militantes comunistas "não devem desertar, senão quando tenham de acompanhar uma deserção colectiva ou corram iminente perigo de ser presos em resultado da sua acção revolucionária" (Avante!, 1967: 382).

\section{Uma "sociedade dualista em evolução"}

No final dos anos sessenta, assiste-se em Portugal à intensificação da tendência de concentração e modernização da indústria que se vinha desenhando desde os inícios da década. A sociedade portuguesa, eminentemente rural e 
dominada pelo campesinato, passa a poder definir-se, nas palavras de Adérito Sedas Nunes em 1964 (2000: 25-84), como uma "sociedade dualista em evolução", marcada pela permanência conjunta e conflitual de valores, atitudes e comportamentos tradicionais e modernos. Pela primeira vez, parecia haver "uma alternativa industrial ao emprego agrícola, o que implicava uma nova organização do trabalho, salários superiores e emprego durante muito mais tempo em cada ano". Assim, entre 1960 e 1973 registou-se o "maior crescimento económico da história do país" (Barreto, 2000: 70). Este surto de industrialização é acompanhado por uma série de alterações que contribuem para uma mudança ao nível das mentalidades.

Em primeiro lugar, anote-se o afluxo crescente de estrangeiros a Portugal, sobretudo à sua costa marítima. Se, em 1959, os visitantes estrangeiros que deram entrada no país não chegavam a 300 000, em 1973 esse número situou-se já acima dos quatro milhões (Telo, 1989: 86). A população portuguesa, tradicionalmente isolada do exterior, tomava agora contacto directo, sobretudo nos meses de Verão, com os ingleses, franceses ou alemães que visitavam o país. Por outro lado, é também por estes anos que se intensifica o movimento inverso: a saída dos portugueses da sua pátria. A emigração, habitualmente direccionada para os territórios africanos e americanos, desloca-se a uma grande velocidade para a Europa, nomeadamente para França. Se até finais de cinquenta, os números se encontravam estabilizados nas três dezenas de milhares, entre 1958 e 1974 emigraram 1,5 milhões de indivíduos, número impressionante se se tiver em conta que o país tinha na altura pouco mais de oito milhões de habitantes. Note-se, além do mais, que esta cifra contém alguma subestimação, já que, para além da emigração legal, apenas tem em conta a emigração clandestina para França, para onde se deslocam, entre 1969 e 1971, cerca de 350000 portugueses, mais de 90\% dos quais clandestinamente (Freitas, 1989: 191-200; Pereira, 2009). Às famílias das zonas de emigração tradicional juntam-se agora famílias de zonas urbanas com os filhos ameaçados de incorporação ou jovens em fuga do destino africano e em busca de um ambiente social mais arejado.

Refira-se ainda a abertura efectuada no âmbito da comunicação e da imprensa. Neste processo, coube papel fundamental à televisão. Se, em 1960, três anos depois do início regular das emissões da RTP (Radiotelevisão Portuguesa), existiam em Portugal 31256 televisores, em 1974 contavam-se já 722315 aparelhos, o que significa que o número tinha crescido vinte e quatro vezes. De repente, imagens do "Vietname, de Hollywood, de Maio de 68 ou da missa na Basílica de S. Pedro, entram pelo lar dos portugueses, alterando de forma permanente a sua visão do mundo que, até aí, pouco excedera a vila ou aldeia" (Telo, 1989: 87). Por mais que o regime procurasse 
resistir a esta tendência, proibindo manifestações públicas, censurando os meios de comunicação, inspeccionando cuidadosamente as fronteiras do dito, era praticamente impossível controlar a entrada dos novos meios de consumo de massa que, de modo inquestionável, iam ajudando a moldar a face da juventude.

A música, o cinema, a literatura, a banda desenhada, o teatro ou o vestuário foram, deste modo, servindo como veículos de questionamento do status quo, explicitando uma mudança em curso: a juventude urbana e escolarizada - ou quem dela estava próxima - deixara de se ver como uma amálgama de sujeitos em processo inacabado de integração social, para passar a agir, pensar e sentir segundo modalidades próprias, quase sempre em desacerto com a retórica isolacionista do regime e com alguns traços dominantes do conservadorismo moral (Bebiano, 2003).

Ainda assim, em Portugal, foi essencialmente a versão combativa da cultura sixtie que mais fortemente se afirmou. Para alguns, e ao contrário do que aconteceu noutros países, "o movimento hippy místico" nunca foi objecto de construção simbólica no país (Resende e Vieira, 1992: 134). Numa linha distinta, Rui Bebiano (2003) coteja vários indícios dessa recepção, ainda que claramente subordinados à urgência do discurso politizado. A isto não é certamente alheia a persistência do fantasma da Guerra Colonial, bem como a repressão política, a extensão aos vários domínios de uma moral conservadora de raiz católica e o fraco desenvolvimento urbano do país. No próprio campo plurifacetado do oposicionismo, condutas hedonísticas e anti-hierárquicas eram vistas como inconciliáveis com a abnegação exigida pela causa "antifascista" e com os cuidados conspirativos que a situação política impunha a todos aqueles que pretendessem lutar organizadamente contra o regime.

\section{Marcelismo: a derradeira estação}

Em Agosto de 1968, António de Oliveira Salazar, então com 79 anos, cai de uma cadeira na sua casa de férias, no Forte de São João do Estoril, e deixa de ter capacidade de governar. Para o seu lugar é nomeado Marcelo Caetano, dezassete anos mais novo que Salazar, e que mantinha uma ligação ao Estado Novo desde a sua fundação. Apesar disso, ganhara reputação de liberal durante os anos 50 e 60, particularmente após a sua demissão do cargo de reitor da Universidade de Lisboa, em 1962, na sequência da invasão pela polícia das instalações académicas. Afastado da política activa desde essa altura, guiara, nos bastidores, uma espécie de "partido informal”, procurando "marcar a diferença; acumular força e influência no seio do regime; esperar pelo momento certo da sucessão” (Rosas, 1994: 507). 
O projecto político de Marcelo Caetano consistia num "programa de abertura e descompressão do regime, com laivos tecnocráticos e desenvolvimentistas" (Rosas e Oliveira, 2004: 11-12). Apostado em unir as faixas ultraconservadoras e liberalizantes da sociedade, Marcelo sintetizou o seu programa na expressão "renovação na continuidade". Se a "continuidade" significava o alinhamento no filão jurídico-institucional do Estado Novo, bem como a manutenção dos territórios ultramarinos como questão nacional, e até mesmo civilizacional, de primordial importância, a "renovação" espelhava-se numa série de medidas de descompressão política que configurariam a chamada "primavera marcelista": regresso do exílio do socialista Mário Soares, em Outubro de 1968, e de António Ferreira Gomes, bispo do Porto, em Julho de 1969; limitação de certos poderes da polícia política e sua mudança de Polícia Internacional de Defesa do Estado (PIDE) para Direcção-Geral de Segurança (DGS), em Novembro de 1969; aprovação, em Abril de 1969, de nova legislação sindical que dispensava as direcções sindicais eleitas de homologação; transformação da União Nacional em Acção Nacional Popular, em Fevereiro de 1970, e sua abertura a novas correntes, de que é exemplo maior a integração nas suas listas para as eleições de 1969 do sector que ficou conhecido como "ala liberal".

$\mathrm{Na}$ alvorada dos anos 70, a manutenção do esforço militar em África sacrificou a liberalização e, com ela, o próprio regime. A polícia política volta a retomar o seu papel repressivo, não apenas contra o PCP e a extrema-esquerda, mas também contra sectores ideológicos mais moderados. Intensifica-se a repressão às franjas oposicionistas católicas, num processo que culminaria, em 1973, em prisões e demissões compulsivas da função pública após uma vigília pela paz decorrida na Capela do Rato, em Lisboa. No interior do governo, é rejeitado o projecto-lei sobre liberdade de imprensa, apresentado na Assembleia Nacional pelos deputados da ala liberal, assinalando uma tendência de fechamento do regime que se faria notar novamente na revisão constitucional de 1971, onde são recusadas todas as propostas oriundas deste sector.

\section{A evolução das oposições radicais e a questão do anticolonialismo}

Este processo de endurecimento caminha a par com uma consolidação da dinâmica oposicionista. A partir de 1970, crescem as greves, os protestos e a agitação social; forma-se a Intersindical, reunindo alguns sindicatos desafectos ao regime; definem-se gestos de oposição ao regime em franjas localizadas do catolicismo, particularmente activas na denúncia da guerra; inicia-se a oposição armada ao Estado Novo, levada a cabo por grupos civis de índole político-militar apostados em desgastar o regime - a ARA (Acção 
Revolucionária Armada), ligada ao PCP, a LUAR (Liga de Unidade e Acção Revolucionária) e as BR (Brigadas Revolucionárias); prolifera uma miríade de pequenos agrupamentos esquerdistas que vêm disputar a hegemonia do PCP nas universidades, conseguindo, em alguns casos, penetrar no território operário e sindical (Cardina, 2010).

Em regra, estes novos grupos eram herdeiros do estilhaçamento das organizações-mãe da esquerda marxista-leninista portuguesa, a FAP (Frente de Acção Popular) e o CMLP (Comité Marxista-Leninista Português), fundadas a partir da ruptura de Francisco Martins Rodrigues com o PCP, em Agosto de 1963. Nesta data, Martins Rodrigues apresenta as suas críticas numa reunião do Comité Central realizada em Moscovo, sintetizadas depois no documento Luta Pacífica e Luta Armada no Nosso Movimento. Aqui se propõe uma revolução proletária armada, em detrimento da linha dominante no partido, assente numa "aliança de classes" e na tese da "revolução democrática e nacional", considerada por Martins Rodrigues uma "deturpação pacifista do leninismo” (1970: 18). Tendo abandonado pouco tempo depois o PCP, cria, com um pequeno núcleo, a FAP, vocacionada para a luta armada e, em Abril de 1964, o CMLP, embrião de um futuro e "verdadeiro" Partido Comunista. Ambas as organizações, praticamente indistintas, seriam fortemente atingidas pela polícia em 1965 e 1966, sendo os seus principais dirigentes condenados a pesadas penas de prisão.

Um crescente e intricado divisionismo levaria à fragmentação da FAP/CMLP numa série de novos grupos. Rotulando o PCP de "revisionista" e "reformista", todos eles reclamavam para si a "pureza" dos princípios marxistas-leninistas, que entretanto se haviam deslocado da União Soviética para países como a China e a Albânia. Apesar da exiguidade de muitas delas, quase todas estas estruturas têm os seus órgãos "de massas" e "teóricos", e dedicam-se a um intenso trabalho de agitação. Uma parte do activismo é desenvolvida no "exterior", isto é, na emigração - especialmente a que se encontra instalada em França - por herdeiros do CMLP em constantes e azedos processos de cisão. No "interior" destacam-se dois grupos: o MRPP (Movimento Reorganizativo do Partido do Proletariado), fundado em Setembro de 1970 a partir de uma estrutura estudantil lisboeta; e a OCMLP (Organização Comunista Marxista-Leninista Portuguesa), criada em finais de 1972 a partir da fusão entre $O$ Comunista, actuante junto da emigração, e O Grito do Povo, especialmente radicado no norte do país.

A estas organizações presidem uma série de características que vêm renovar o modus operandi do oposicionismo. Em primeiro lugar, erguem como bandeiras privilegiadas a luta contra a Guerra Colonial e a defesa da revolução proletária, através de um discurso radicalizado e voluntarista 
(Bebiano, 2001). Em segundo lugar, elegem novos ícones políticos, como Ho Chi Minh, Mao Tsé Tung e Che Guevara, marcados por um "voluntarismo fundamentalmente anti-realista" que, nos dois últimos, se estende à própria contestação ideológica, política e cultural da norma soviética (Frank, 2000: 36). Em terceiro lugar, e como consequência disso, é introduzido um estilo diferente de confrontação com o poder, mais directo e audacioso, que passava pela promoção de manifestações temerárias, pela distribuição de panfletos em pleno dia ou pelo apedrejamento de instituições bancárias. Essencialmente localizado nos meios estudantis e da juventude operária, este novo activismo não deixou de contaminar espaços sociais contíguos, fenómeno atestado pela crescente atenção policial que lhe passa a ser dedicada (Pereira, 1989: 103; Pimentel, 2007: 187).

\section{Guerra à guerra}

Iniciadas em Fevereiro de 1961, em Angola, e progressivamente estendidas a outros territórios - Guiné, em Janeiro de 1963 e Moçambique, em Agosto de 1964 -, as guerras que o Estado português travava contra os movimentos independentistas africanos afectavam directamente os jovens universitários. Quase todos os rapazes sabiam que tinham de cumprir um longo serviço militar de pelo menos três anos, em condições de risco físico e psicológico acentuado. Ainda assim, o tema da guerra era raras vezes abordado de maneira desassombrada e crítica. Um manto de silêncio cobria "uma opinião pública desinformada e controlada, distante dos problemas africanos, mas educada numa intensa mística imperial" (Ribeiro, 2004: 174). Razões culturais - de honra, de orgulho, de masculinidade - estavam-lhe também na base, como observou o escritor Fernando Dacosta em Nascido no Estado Novo: "não ir à tropa, ser dispensado, fizera-se uma inferioridade, um labéu. Ficar-se livre chegava a ser vergonhoso - jovens havia que perdiam namorada e reputação por isso" (2001: 265).

Lentamente, a Guerra Colonial foi provocando um afastamento claro entre os interesses do Estado Novo e as aspirações juvenis. Entre 1961 e 1974, perto de 200000 jovens faltaram à chamada para a tropa. O número de refractários situava-se, entre 1970 e 1972, já acima dos 20\%, contabilizando-se mais de 50000 faltosos nesses três anos (Resenha..., 1988: 258). Tenha-se em conta que, percentualmente, Portugal tinha mais homens em armas do que qualquer país ocidental, à excepção de Israel. A mobilização teria sido equivalente aos EUA colocarem 2,5 milhões de homens no Vietname, em lugar dos cerca de 500000 que lá estiveram (Fernandes, 2002).

Contrastando com a atitude pactuante da generalidade da hierarquia católica, alguns sectores católicos desenvolvem uma acção de timbre pacifista, 
essencialmente caracterizada pela tentativa de romper a censura e informar sobre a guerra. Inscrevem-se aqui as dissensões públicas de padres como Felicidade Alves e Mário de Oliveira, mas também publicações como o Direito à Informação, os Cadernos GEDOC ou o Boletim Anti-Colonial, e vigílias pela paz como as realizadas nos últimos dias de 1968, em S. Domingos, e de 1972, na Capela do Rato. Muitos "católicos progressistas", aliás, distinguiram-se no auxílio às passagens "a salto" da fronteira luso-espanhola, como é o caso de Natália Teotónio Pereira e Nuno Teotónio Pereira.

A contestação ao conflito mantinha-se, no entanto, circunscrita a alguns círculos de reflexão crítica. Em Fevereiro de 1968, uma manifestação contra a Guerra do Vietname frente à Embaixada dos EUA, organizada por sectores da emergente extrema-esquerda, havia já indirectamente trazido o tema para a rua. No entanto, num importante conflito estudantil ocorrido em Coimbra, em 1969, a Guerra Colonial ainda está ausente do catálogo explícito de reivindicações, se bem que logo a seguir se torne a questão primordial do activismo nas universidades (Cardina, 2008).

Ao contrário do PCP, por vezes cauteloso na abordagem explícita do tema, os grupos m-l colocaram a Guerra Colonial no cimo da agenda reivindicativa. Aconselhando a deserção, os maoístas distanciavam-se da proposta de ir para a frente de combate, que o PCP defendia para os seus militantes. A OCMLP propunha mesmo a deserção com armas no final da recruta, procurando conjugar a recusa da guerra colonial com a necessária aprendizagem do manejo das armas. O Manifesto ao Soldado explicitava:

Quando desertares, tenta de todas as formas expropriar armas, explosivos, fardas, documentos, mapas, etc... Se tiveres um amigo revolucionário de toda a confiança entrega-lhe o material. Se não, enterra o material, protegendo-o bem da humidade, ou esconde-o num sítio seguro: quando a revolução necessitar, as armas estarão lá prontas a servir. (O Grito do Povo, 1973: 3)

O posicionamento perante a Guerra Colonial - desertar ou manter-se no exército - terá sido, muitas vezes, crucial quanto à escolha do campo político. Repare-se na forma como Hélder Costa, um dos principais dirigentes de O Comunista/OCMLP, relata em entrevista o seu confronto com esta questão:

Os gajos [PCP] andaram um ano e tal atrás de mim. Eu depois fui de férias, meses, comprei em Paris o Manifesto do Partido Comunista, a história do socialismo, aprendi à brava, li aquilo nas férias, e quando voltei encontrei o gajo e disse: "é pá, quero entrar. Estive a ver, a ler umas coisas, e como isso é uma decisão para a vida...". "P'ra 
vida?", diz ele. E eu disse: “é pá, é, um gajo que escolhe, é para isso”. O tipo ficou muito impressionado e eu logo: "Guerra Colonial". "É pá, temos de ir e tal”, responde o gajo. "Então mas porquê? Porra, eu tenho lá os meus camaradas e depois como é que é? A gente encontra-se no mato e tal, ó pá, Viva a Prá-Kys-Tão!? [República de Coimbra onde viveu e confraternizou com estudantes africanos]" Não dá (risos)! O gajo começa a olhar para mim: "ah, tem de ser, para fazer a guerra mais humana”. "É pá, estamos enganados, não há problema nenhum, mas não entro”. Foi assim, foi simples. Para mim era uma questão chave. (Costa, 2007)

Para o PCP (m-l) [Partido Comunista de Portugal (marxista-leninista)], nascido em França, no início da década de setenta, a partir do antigo CMLP, a palavra de ordem era "ir para a tropa" para "aprender a manejar as armas" e fazer "agitação e propaganda anticolonialista junto dos soldados prestes a partir para a guerra". Coloca-se, no entanto, a questão: "desertar antes do embarque ou seguir para as colónias?” Tendo em conta a desorganização actual do proletariado, que impossibilitava um "autêntico trabalho revolucionário no seio do corpo expedicionário”, propõe-se a deserção. Por outro lado, e ao contrário das situações em que os comunistas devem participar nas guerras imperialistas para aproveitar o armamento da classe operária, neste caso "a burguesia instalada em S. Bento nunca perde o controlo das massas armadas, pois estas, ao regressarem a Portugal, vêm desarmadas". Assim sendo, "desertar é, afinal, o mal menor" (Estrela Vermelha, 1972: 13).

Nem sempre a deserção equivalia a uma passagem "a salto" para o estrangeiro. Uma hipótese menos óbvia, mas ainda assim levada a cabo, foi a entrada para a clandestinidade no "interior", com o objectivo de realizar tarefas directivas ou proletarizando-se sob uma identidade falsa. $\mathrm{Na}$ OCMLP operaram-se, a partir de 1971, muitos processos de "implantação" nas fábricas, a maioria envolvendo estudantes que decidem efectuar um percurso voluntário de mobilidade social descendente. Pedro Bacelar de Vasconcelos foi um deles, como conta:

Em Setembro de 1973 desertei com todo o material de guerra que consegui meter no saco ... Por vontade minha entrei na clandestinidade e fui trabalhar para uma fábrica na zona da Covilhã. A minha entrada formal na OCMLP só se dá aí, quando decido "ir para a fábrica". (Vasconcelos, 2008)

Por outro lado, a deserção não era uma prática estimulada nestes grupos de maneira uniforme. Há a assinalar a posição dissonante da URML (Unidade Revolucionária Marxista-Leninista), para quem a deserção representava uma "atitude individualista e oportunista" que conduzia "necessariamente 
à perda de elementos com os quais a Revolução Proletária poderia contar" (Folha Comunista, 1971:2). Registe-se ainda o facto de alguns grupos vedarem a deserção aos militantes mais responsáveis, optando pela sua permanência no interior em situação de clandestinidade. Vidaul Ferreira, um dos fundadores do MRPP, afirma:

Uma pessoa como eu não ia para França. Certas pessoas nossas que desertavam da guerra, sim. Agora, se eu fosse, íamos todos. Uma das críticas que fazíamos ao PCP era precisamente essa: "Então o Cunhal dirige o PCP e está em Paris, na Rússia, etc." Para nós era importante estar cá. (Ferreira, 2007)

O MRPP estipulava amiúde a preferência de que as deserções fossem “colectivas”. Em Junho de 1971, o Luta Popular exortava à organização "por pelotão, por batalhão, por companhia, de núcleos de resistência anticolonial que fomentem a greve à recruta, a sabotagem do material, a desobediência e a deserção colectivas e a constante agitação contra a guerra" (Luta Popular, 1971: 4). A sua estrutura própria na tropa, a RPAC (Resistência Popular Anti-Colonial), embora reivindicasse a organização de deserções colectivas, colocava a ênfase na sua propaganda na necessidade dos soldados e marinheiros virarem as armas contra a burguesia, transformando a Guerra Colonial numa guerra civil revolucionária.

O MRPP foi, na verdade, o grupo que maior visibilidade alcançou no campo do activismo anticolonial. Com recurso a uma linguagem triunfalista decalcada dos cartazes da Revolução Cultural, o primeiro número do órgão Luta Popular, datado de Fevereiro de 1971, intitulava na primeira página: "Viva a Grande, Gloriosa e Justa Luta Revolucionária de Libertação Nacional dos Povos Oprimidos das Colónias" (Luta Popular, 1971: 1). Mantinham, além disso, uma clara hostilidade para com o PCP, sendo, a dada altura, o único grupo maoísta que não se propunha "reconstruir" o partido, mas sim "fundá-lo", já que advogavam nunca ter existido um partido comunista em Portugal. O assassínio às mãos da DGS do seu militante Ribeiro dos Santos viria a intensificar ainda mais esta escalada sectária, acusando militantes comunistas de cumplicidade no homicídio. A restante extrema-esquerda também não era poupada, recebendo o epíteto de "confraria neo-revisionista" (Que Viva Estaline!, 1972).

Quase todos os grupos tinham estruturas criadas propositadamente para o combate anticolonial. A OCMLP dinamizava para essa função os Comités Servir o Povo, actuantes no Porto e em Coimbra. A URML, o PRP (Partido Revolucionário do Proletariado) e as CBS (Comissões de Base Socialistas) criaram em 1973 os CULIC (Comités Unitários para a Libertação Imediata 
das Colónias). O CRML (Comité Revolucionário Marxista-Leninista) confundia-se com os Comités Guerra Popular, presentes em algumas escolas de Lisboa, e que eram a sua única face visível, resultado de este grupo entender a Guerra Colonial como "a contradição principal na formação social portuguesa” (Guerra Popular, 1972, 4). Durante estes primeiros anos da década de setenta, emergem variados CLACs (Comités de Luta Anti-Colonial), impulsionados por militantes do PCP (m-l) e do MRPP mas contando com uma forte componente informal e descentralizada. Para além destas estruturas, assentes no meio estudantil, e que eram aquelas que desenvolviam um activismo mais aguerrido e ruidoso, as diferentes organizações maoístas criaram ainda organizações, em regra exíguas, nos quartéis e em alguns focos operários.

$\mathrm{Na}$ emigração política, designadamente em França, a extrema-esquerda foi animando jornais como o Jornal do Emigrante (1968-1972), A Voz do Povo (1968-75), O Salto (1970-74), O Alarme! (1972-75), Ergue-te e Luta (1972-73), Alavanca (1972-74) ou A Voz do Desertor (1973), particularmente focados na denúncia do colonialismo e no apoio aos movimentos de libertação africanos. Muitos destes boletins, apesar de efémeros, contaram com a caução de importantes intelectuais franceses, como Marguerite Duras, François Châtelet e Jean-Paul Sartre. Ao mesmo tempo, o trabalho cultural levado a cabo em associações de emigrantes, fomentando-se grupos de teatro, cursos de alfabetização ou convívios com música de intervenção, aprofundava a ligação entre o desertor e o emigrado económico, que constituía o grosso da comunidade lusa (Clímaco, 1992).

No início dos anos setenta, aumentam os jovens portugueses noutros países da Europa, muitas vezes aí chegados em situações de grande precariedade e que contaram frequentemente com o apoio de estruturas cívicas e religiosas, de militantes de esquerda locais ou de colectivos direccionados para a condenação do colonialismo, como o Angola Comité, da Holanda. O PCP (m-l) e O Comunista/OCMLP contavam com os Comités de Desertores, animados por activistas que frequentemente acumulavam ainda a participação em associações de emigrantes dinamizadas pelos referidos grupos - caso da Associação Resistência e Trabalho, na Holanda, ligada ao PCP (m-l) - e a militância nas células partidárias (Cordeiro, 2010). Registe-se ainda o impacto causado por algumas deserções colectivas. É o caso da evasão, em 1970, de sete antigos alunos da Academia Militar, e mais tarde, em 1973, da deserção de cinco marinheiros portugueses durante a paragem da fragata Almirante Magalhães Correia em portos dinamarqueses, estimulada pelos Comités de Desertores da Suécia e da Dinamarca, ligados a O Comunista/OCMLP. 


\section{Retóricas da violência}

As práticas e os discursos provenientes da área $\mathrm{m}$-l sustentaram-se em exercícios de legitimação da violência, vista como um modo de, simultaneamente, resistir à tirania e alcançar o poder. Como se afirmava num jornal da URML, "a essência do Estado capitalista reside na violência contra-revolucionária das classes exploradoras e só poderá ser destruída pela violência revolucionária dos oprimidos e explorados" (Revolução Proletária, 1973: 2). Assim, para os grupos de matriz maoísta, tratava-se, não de condenar a violência da guerra, mas de mostrar que a iniquidade desta residia no seu carácter imperialista. "Guerra do povo à Guerra Colonial", palavra de ordem usada em manifestações anticolonialistas na ponta final do regime, servia precisamente para sintetizar essa ideia (Luta Popular, 1973: 11-12).

A ideia de revolução enquanto processo levado a cabo pelas massas populares armadas, guiadas por um partido disciplinado regido pelo centralismo democrático, aparecia naturalmente como um dogma indiscutível na produção teórica destes grupos. O modelo do "povo em armas" e a necessidade de um tipo de militante disciplinado e abnegado, na linha do que foi explicitado por Lenine em Que Fazer?, era assim declarado pelos CCR (M-L) (Comités Comunistas Revolucionários Marxistas-Leninistas):

A burguesia jamais cederá pacificamente o poder; por isso afastamos todas as ilusões quanto à possibilidade de transformação pacífica e suave da ditadura da burguesia em ditadura do proletariado. Em segundo lugar, nós pretendemos que a luta armada seja uma verdadeira luta popular... Nisto nos distinguimos dos castristas, que querem substituir a luta armada das massas trabalhadoras pela acção violenta de um punhado de heróis isolados. (Viva o Comunismo!, 1970, 2/3)

No entanto, a relação problemática que se foi estabelecendo com o fenómeno cubano permite matizar esta ideia e, simultaneamente, apontar a existência de outras lógicas de entender a violência neste campo político. Na verdade, logo no início da década de sessenta, Cuba foi motivo de afeição junto de sectores, dentro e fora do PCP, que contestavam a política de alianças deste partido. Francisco Martins Rodrigues, então em ruptura com o PCP e em vias de criar a FAP e o CMLP, recordou a presença do apelo de Cuba "mesmo na base do partido", já que era uma inaudita "transformação revolucionária, a favor dos trabalhadores, que optava pela via armada", e que mostrava ser possível uma via insurreccional distante do anticomunismo putchista dos republicanos (Rodrigues, 2008). Rui d'Espiney, destacado dirigente do CMLP inicial, nota que "estávamos 
todos marcados por Cuba, pela ideia de que o regime não caía pacificamente" (D'Espiney, 2008).

Ainda que defendendo a tese do "levantamento popular armado", nos primeiros tempos do maoísmo português (1964-1966) denota-se assim uma certa simpatia pela impaciência revolucionária cubana, que viria a reaparecer no CMLP nos anos seguintes, dando azo a protestos internos, autocríticas e cisões. Os núcleos $O$ Comunista, agrupando de forma federativa diferentes comités espalhados pela Europa, foram um dos colectivos no qual este imaginário mais se expressou. Hélder Costa, um dos seus principais animadores, realça a questão da seguinte forma:

Eu também tinha uma grande admiração pela revolução cubana. Por terem começado uma revolução ali, sozinhos, numa ilha, os boicotes, a invasão e os gajos a resistir... E a questão de Cuba, do Che Guevara, começou a criar um determinado tipo de fricções. Eu tinha uma posição, que não era teórica, era mais ao nível da sensibilidade, como se sente as coisas... Eu nunca fui adepto da teoria do foco. Mas fui sempre admirador dos gajos que queriam jogar à porrada. (Costa, 2007)

Foi naturalmente nos grupos que levaram a cabo a luta armada que o impacto de Cuba mais se manifestou, ainda que muitas vezes sem um reenvio ideológico explícito. A experiência fracassada da tomada da Covilhã pela LUAR, em 1968, não pode deixar de evocar a busca de uma qualquer Sierra Maestra a partir da qual se daria a insurreição contra o regime. ${ }^{2}$ Também as BR (Brigadas Revolucionárias), não obstante o compósito heteróclito de influências que procuravam conjugar, bebiam de alguma maneira no imaginário guevarista. Pedro Goulart, militante desta área política, recorda a "alegria" com que soube desse "momento extremamente marcante" que foi a vitória das tropas de Fidel e Guevara, e de como Cuba nesses anos representou a negação do "fatalismo geográfico que parecia impor a dependência dos povos da América Latina em relação ao todo-poderoso vizinho do Norte" (Goulart, 2002: 15-17).

Mesmo uma estrutura assumidamente maoísta, como é o caso da OCMLP, chegou a assistir, nos inícios de 1974, a uma tentativa de imposição de uma linha guerrilheirista. A acção é assim descrita por José Queirós, um dos

\footnotetext{
${ }^{2}$ A operação foi preparada a partir de Paris e consistia na ocupação da Covilhã por um punhado de militantes armados, com corte de comunicações e tomada dos postos da PSP e GNR. Em Agosto de 1968, os operacionais da LUAR atravessaram a fronteira luso-espanhola, mas uma parte do grupo, abordada após ter cometido uma infracção rodoviária, pôs-se em fuga e foi detida em Moncorvo. Entre os capturados encontrava-se Palma Inácio, que deveria dirigir a operação, e Daniel Teixeira, um jovem militante a estudar na Bélgica e que viria a morrer em Caxias, a 24 de Outubro de 1968, por falta de assistência médica.
} 
elementos da direcção que não alinhou na nova estratégia e que esteve, por isso, preso pelos militantes da facção emergente:

Foi basicamente um conflito entre o que chamávamos uma "linha de massas" (ou, na linguagem da época, de "reconstrução do partido na luta de massas") e uma linha guerrilheirista, que queria armar os Comités Operários e desencadear a violência... Só que nada disso era ainda assumido com muita clareza, e vinha embrulhado num discurso ideológico que misturava a fanfarronada radicalista com slogans inspirados na revolução cultural chinesa. (Queirós, 2008)

Tenham ou não cedido à "tentação da luta armada" (Bebiano, 2005), os grupos maoístas portugueses foram marcados por um desejo de ruptura na qual a presença das armas era vista como um elemento necessário para o derrube da ditadura e para a instauração de uma sociedade sem classes. Ao contrário do PCP, que se alimentou fortemente de uma ideia de "identidade nacional" (Neves, 2008), estes colectivos colocaram o acento tónico no internacionalismo e no anti-imperialismo de cariz insurreccional, patente nos artigos de revistas e jornais, no corpo dos comunicados ou nas palavras de ordem das manifestações.

As próprias datas comemoradas pelos presos políticos são ilustrativas a este respeito. Segundo o grupo A Vanguarda, os "revisionistas" - designação dada aos militantes do PCP - teriam comemorado, na cadeia de Peniche, o 5 de Outubro (de 1910, implantação da República), dia em que "a burguesia liberal triunfa sobre a monarquia" e o $10^{\circ}$ de Dezembro (de 1640), dia da restauração da independência, em que se dá "o triunfo da monarquia portuguesa sobre o domínio da monarquia espanhola”. Por seu turno, os "marxistas-leninistas", entre outras datas, comemoraram o aniversário da Revolução Chinesa, da Revolução de Outubro, o início da luta armada em Angola, o centenário do nascimento de Lenine e prestaram homenagem a Ho Chi Minh no dia da sua morte (As lutas..., s.d.). Refira-se que, na cadeia de Peniche, os presos da extrema-esquerda se vão progressivamente afastando dos presos do PCP até que, por volta de 1970, já não existem contactos físicos nem estratégias comuns de luta. Sucedem-se uma série de conflitos com as autoridades prisionais, muitos deles acabando em greves da fome, nas quais os elementos do PCP não participam.

A 25 de Abril de 1974, quando um golpe militar conduzido pelas patentes intermédias do exército, cansadas de uma guerra infindável em três frentes de combate (Angola, Moçambique e Guiné-Bissau), pôs fim à mais velha ditadura da Europa, a saída imediata da população às ruas provou a existência de uma "quarta frente", desalinhada com o regime. Não 
sendo única, a acção e a retórica promovida pela constelação dos grupos e organizações $\mathrm{m}$-l foi porventura a mais ruidosa, extravasando claramente os círculos restritos da militância e promovendo uma politização extrema de alguns sectores sociais, processo que é preciso considerar para se perceber o agitado momento revolucionário que ocorreu entre 1974 e 1975.

Enquanto o mundo ia assistindo à consolidação triunfante dos independentismos anticoloniais e a ditadura portuguesa persistia em manter o seu domínio ultramarino, estes sectores animaram um horizonte de intervenção de traços fortemente internacionalistas, no qual a recusa da guerra se fez por intermédio de lógicas políticas que não deixavam de conceder um lugar central à razão das armas. Se a Guerra Colonial prolongada e o autoritarismo institucionalizado explicam em parte as conexões mais ténues com a vertente libertária e hedonista do universo contestatário da época, também ajudam a compreender a relativa relevância do maoísmo no país. Marcados por um forte sentido de activismo e por uma feroz crítica ideológica ao imperialismo, estes sectores foram enérgicos na defesa da deserção, na criação de estruturas frentistas dedicadas ao combate anticolonial e na difusão de práticas e atitudes, particularmente sedutoras para a juventude, de desprezo e antagonismo perante a persistência militar portuguesa em África.

\section{Referências bibliográficas}

\section{Publicações periódicas e outros documentos (anos consultados)}

As lutas dos revolucionários portugueses no interior das prisões (Grupo de Base "A Vanguarda" do Comité Marxista-Leninista Português) (s.d.).

Avante! (Partido Comunista Português) (1961-1967).

Estrela Vermelha (Partido Comunista de Portugal Marxista-Leninista) (1972).

Folba Comunista (Unidade Revolucionária Marxista-Leninista) (1971).

Guerra Popular (Comité Revolucionário Marxista-Leninista) (1972).

Luta Popular (Movimento Reorganizativo do Partido do Proletariado) (1971-3).

O Grito do Povo (Organização Comunista Marxista-Leninista Portuguesa) (1973).

Que Viva Estaline! - Resolução do Comité Lenine a propósito do grande Estaline (Movimento Reorganizativo do Partido do Proletariado) (1972).

Revolução Proletária (Unidade Revolucionária Marxista-Leninista) (1973).

Viva o Comunismo! (Comités Comunistas Revolucionários Marxistas-Leninistas) (1970).

\section{Entrevistas}

Costa, Hélder (2007), Entrevista ao autor. Lisboa, 5 de Outubro.

D’Espiney, Rui (2008), Entrevista ao autor. Setúbal, 1 de Julho. 
Ferreira, Vidaul (2007), Entrevista ao autor. Lisboa, 5 de Outubro.

Queirós, José (2008), Entrevista ao autor. Porto, 7 de Fevereiro.

Rodrigues, Francisco Martins (2008), Entrevista ao autor. Lisboa, 29 de Janeiro.

Vasconcelos, Pedro Bacelar (2008), Entrevista ao autor. Porto, 7 de Fevereiro.

\section{Bibliografia}

Alexander, Robert J. (1999), International Maoism in the Developing World. Westport, CT: Praeger.

Alexander, Robert J. (2001), Maoism in the Developed World. Westport, CT: Praeger. Alexandre, Valentim (2000), Velho Brasil, novas Áfricas. Portugal e o Império (1808-1975).

Porto: Afrontamento.

Aron, Raymond (1968), La Révolution introuvable. Paris: Fayard.

Avakian, Bob (2005), From Ike to Mao and beyond. My Journey from Mainstream America to Revolutionary Communist. Chicago: Insight Press.

Badiou, Alain (2008), "Communist Hypothesis", New Left Review, 49, 29-42.

Barreto, António (org.) (2000), A situação social em Portugal, 1960-1999. Lisboa: Imprensa de Ciências Sociais.

Bebiano, Rui (2001), "A esquerda e a oposição à guerra colonial”, in Rui de Azevedo Teixeira (org.), A Guerra do Ultramar. Realidade e ficção. Lisboa: Editorial Notícias, 293-313

Bebiano, Rui (2003), O poder da imaginação. Juventude, rebeldia e resistência nos anos 60. Coimbra: Angelus Novus.

Bebiano, Rui (2005), "Contestação do regime e tentação da luta armada sob o marcelismo”, Revista Portuguesa de História, 37, 65-104.

Berman, Paul (2007), O poder e os idealistas. A geração idealista de 68 e a sua subida ao poder. Lisboa: Alêtheia Editores.

Bloom, Allan (1987), The Closing of the American Mind. New York: Simon \& Schuster.

Cardina, Miguel (2008), A tradição da contestação. Resistência estudantil em Coimbra no marcelismo. Coimbra: Angelus Novus.

Cardina, Miguel (2010), A esquerda radical. Coimbra: Angelus Novus.

Cardoso, António Monteiro (2009), "Desertar ou ficar. Os comunistas e a incorporação no exército colonial”. II Colóquio Os Comunistas em Portugal - 1921-2009. Org. Revista Política Operária. Lisboa, Biblioteca Museu República e Resistência.

Cordeiro, José Manuel Lopes Cordeiro (2010), "Desertar contra a guerra colonial - os núcleos de desertores na Europa”. Seminário Exílios contra a Ditadura. Org. Instituto de História Contemporânea. Lisboa, IHC.

Citações do Presidente Mao (1972), Pequim: Edições em Língua Estrangeira.

Clímaco, Cristina (1992), La presse de l'émigration politique portugaise en France-analyse du journal O Salto. 1970-1974. Paris: Université de Paris VII, Mémoire de DEA.

Dacosta, Fernando (2001), Nascido no Estado Novo. Lisboa: Editorial Notícias. 
Dressen, Marnix (1999), De l'amphi à l'établi. Les étudiants maoïstes à l'usine (1967-1989). Paris: Belin.

Elbaum, Max (2002), Revolution in the Air. Sixties Radicals Turn to Lenin, Mao and Che. London/New York: Verso.

Fanon, Franz (2002), Les damnés de la terre. Paris: La Découverte.

Fernandes, Álvaro (2002), "Uma guerra de baixa intensidade e longa duração”, História, 51, 48-53.

Feuer, Lewis (1969), The Conflict of Generations: The Character and Significance of Student Movements. New York: Basic Books.

Fields, A. Belden (1988), Trotskyism and Maoism. Theory and Practice in France and the United States. New York: Autonomedia.

Frank, Robert (2000), "Imaginaire politique et figures symboliques internationales: Castro, Hô, Mao et le Che", in G. Dreyfus-Armand et al. (orgs.), Les Années 68. Le temps de la contestation. Paris: Complexe, 31-47.

Freitas, Eduardo (1989), “O fenómeno emigratório: a diáspora europeia”, in A. Reis (org.), Portugal Contemporâneo, vol. V (1958-1974). Lisboa: Alfa, 191-200.

Gitlin, Todd (1987), The Sixties. Years of Hope, Days of Rage. New York: Bantam Books.

Goulart, Pedro (2002), Resistência. Lisboa: Dinossauro.

Jameson, Fredric (1984), "Periodizing the Sixties", in S. Sayres; A. Stephensom (orgs.), The Sixties without Apology. Minneapolis: University of Minnesota Press, 178-209.

Katsiaficas, George (1987), The Imagination of the New Left: a Global Analysis of 1968. Boston: South End Press.

Lüthi, Lorenz (2008), The Sino-Soviet Split. Cold War in the Communist World. Princeton: Princeton UP.

Madeira, João (2003), “O PCP e a Questão Colonial - dos fins da guerra ao V Congresso (1943-1957). Estudos do Século XX, 3, 209-243.

Manya, Judith (2004), Le Parti Communiste Portugais et la Question Coloniale 1921-1974. Thèse pour le doctorat en Science Politique, CEAN, Bordeaux.

Martins, Susana (2005), Socialistas na oposição ao Estado Novo. Cruz Quebrada: Casa das Letras.

Marwick, Arthur (1998), The Sixties. Cultural Revolution in Britain, France, Italy and the United States, c.1958-1974. Oxford: Oxford UP.

Neves, José (2008), Comunismo e nacionalismo em Portugal. Política, cultura e história no século XX. Lisboa: Tinta da China.

Nunes, Adérito Sedas (2000), Antologia sociológica. Lisboa: Imprensa de Ciências Sociais.

Pereira, José Pacheco (1989), “O Partido Comunista Português e a Esquerda Revolucionária”, in M. B. Coelho (org.), Portugal. O sistema político e constitucional. 1974-1987. Lisboa: ICS, 79-109. 
Pereira, José Pacheco (2008), "O um dividiu-se em dois". Origens e enquadramento internacional dos movimentos pró-chineses e albaneses dos países ocidentais e em Portugal (1960-65). Lisboa: Alêtheia Editores.

Pereira, Victor (2009), "Ineficiência, fragilização e duplicidade. O velho Estado Novo perante a emigração para França (1960-1968)”, Ler História, 56, 45-68.

Pimentel, Irene (2007), A bistória da PIDE. Mem Martins: Círculo de Leitores/Temas e Debates.

Resende, José; Vieira, Maria Manuel (1992), "Subculturas juvenis nas sociedades modernas: os hippies e os yuppies", Revista Crítica de Ciências Sociais, 35, 131-147.

Resenha histórico-militar das campanhas de África (1961-1974), vol. I. Enquadramento geral (1998). Lisboa: Estado-Maior do Exército.

Ribeiro, Margarida Calafate (2004), Uma história de regressos. Império, Guerra Colonial e pós-colonialismo. Porto: Afrontamento.

Anon [Rodrigues, Francisco Martins] (1970 [1963]), Luta pacífica e luta armada no nosso movimento. S.1.: Edições do Partido.

Rosas, Fernando (1994), O Estado Novo (1926-1974). Lisboa: Círculo de Leitores/Editorial Estampa.

Rosas, Fernando; Oliveira, Pedro Aires (orgs.) (2004), A transição falhada. O marcelismo e o fim do Estado Novo (1968-1974). Lisboa: Editorial Notícias.

Salazar, António de Oliveira (1951), Discursos e notas políticas. 1943-1950. Coimbra: Coimbra Editora.

Silveira, Joel (1989), “As guerras coloniais e a queda do Império”, in António Reis (org.), Portugal Contemporâneo, vol. V (1958-1974). Lisboa: Alfa, 71-106.

Stephens, Julie (1998), Anti-Disciplinary Protest: Sixties Radicalism and Post-Modernism. Cambridge: Cambridge University Press.

Telo, António José (1989), "Portugal, 1958-1974: sociedade em mudança”, in Hipólito de la Torre (org.), Portugal y España en el cambio político (1958-1978). Mérida: UNED, Centro Regional de Extremadura, 73-88.

Varon, Jeremy (2004), Bringing the War Home. The Weather Underground, The Red Army Faction, and Revolucionary Violence in the Sixties and Seventies. Berkeley/Los Angeles/London: University of California Press.

Wallerstein, Immanuel (2008), "Ler Fanon no século xxI", Revista Crítica de Ciências Sociais, 82, 3-12. 